that infusions of adrenaline or noradrenaline in dogs had this effect. Water retention might be expected to lower plasma concentrations of potassium and urea as well as sodium. In fact, uraemia was common and hyperkalaemia sometimes seen (figs 5 and 6 ). Retention of some 1.71 of water would be needed to reduce a plasma sodium concentration from 139 to $134 \mathrm{mmol} / 1$ (fig 2) in a $70 \mathrm{~kg}$ adult; and of some 8.41 to reduce the concentration from 150 to $125 \mathrm{mmol} / \mathrm{l}$ (fig 6).

We found that hyponatraemia and uraemia and rises in serum $L D$ and AST activities were all more severe and prolonged in patients given frusemide (figs 2 and 4). Mortality also increased with increased doses. These findings may have occurred because diuretics were not given to the patients with the least severe infarcts, and the highest dose was given to those with the most severe infarcts. Nevertheless, diuretics may conceivably aggravate events after infarction, and this possibility deserves further investigation. It is perhaps pertinent that observations in congestive heart failure ${ }^{20}$ have similarly prompted the suggestion that diuretics might enhance catabolism of amino-acids and thereby increase the concentration of urea in body fluids.

Biochemical analyses were carried out by the department of clinical biochemistry. We thank $\operatorname{Dr}$ R A L Brewis, consultant physician; resident medical and nursing staff of the coronary care unit; Dr D Appleton, of the department of medical statistics; and Professor $D$ G Julian for their help.

Requests for reprints should be sent to: Dr C T G Flear, University Department of Clinical Biochemistry, Royal Victoria Infirmary, Newcastle upon Tyne NE1 4LP.

\section{References}

1 Oliver, M F, Circulation, 1972, 45, 491.

${ }^{2}$ Vetter, N, et al, Lancet, 1974, 1, 284.

3 Flear, C T G, 尹ournal of Clinical Pathology, 1970, 4, 16.

${ }^{4}$ Flear, C T G, Postgraduate Medical fournal, 1960, 36, 104.

${ }^{5}$ Flear, C T G, in Electrolytes and Cardiovascular Diseases, ed E Bajusz, p 357. Basle, S Karger, 1966.

${ }^{6}$ Flear, C T G, in Compartments, Pools, and Spaces in Medical Physiology, ed P-E E Bergner and C C Lushbaugh, p 53. Washington, US Atomic Energy Commission, Division of Technical Information, 1967.

7 Latner, A L, and Skillen, A W, Lancet, 1961, 2, 1286.

8 Wilhelm, S K, American fournal of Clinical Pathology, 1951, 21, 146.

${ }^{9}$ Dyckner, T, et al, Acta Medica Scandinavica, 1975, 197, 207.

10 Flear, C T G, Singh, C M, and Nandra, G S, communication to the Cardiac Muscle Research Group, Edinburgh, 1976.

${ }^{11}$ Flear, C T G, Bhattacharya, S S, and Nandra, G S, in Nutritional Aspects of Care in the Critically Ill, ed J R Richards and J M Kinney, p 195. Edinburgh, Churchill Livingstone, 1977.

12 De Mello, W C, Fournal of Physiology, 1976, 263, 171.

${ }^{13}$ Hercus, V M, McDowall, R J S, and Mendel, D, fournal of Physiology, 1955, 129, 177 .

${ }^{14}$ McDowall, R J S, Munro, A F, and Zayat, A F, fournal of Physiology, $1955,130,615$.

${ }^{15}$ Glitsch, H G, Reuter, H, and Scholz, H, fournal of Physiology, 1970, 209, 25.

${ }^{16}$ McCance, R A, Lancet, 1936, 1, 823.

${ }^{17}$ Maffly, R H, and Edelman, I S, Progress in Cardiovascular Disease, 1961, 4,80 .

${ }^{18}$ Flear, C T G, and Singh, C M, British fournal of Anaesthesia, 1973, 45, 976.

19 Flear, C T G, Lancet, 1974, 2, 164.

${ }^{20}$ Domenet, J G, and Evans, D W, Quarterly fournal of Medicine, 1969, 149, 117.

(Accepted 16 March 1979)

\title{
Reports by anaesthetists to procurators-fiscal: analysis of "anaesthetic deaths" over 10 years in four Scottish teaching hospitals
}

\author{
A L GILLIES, D S ARTHUR, A L FORREST, J I M LAWSON, A H B MASSON, A A SPENCE
}

British Medical fournal, 1979, 1, 1246-1247

\section{Summary and conclusions}

Review of 489 "anaesthetic deaths" reported to procurators-fiscal over 10 years disclosed only 30 that were thought to justify such reporting. Most of the remainder occurred in patients so desperately ill at the time of operation that death was expected. Postmortem examinations ordered by the Crown authorities in nearly all cases were probably largely unrewarding and mostly unnecessary.

\footnotetext{
University Department of Anaesthesia, Western Infirmary, Glasgow G11 6NT

A L GILLIES, MB, FFARCS, registrar anaesthetist

A A SPENCE, MD, FFARCS, head of department

Department of Anaesthesia, Royal Infirmary, Glasgow

D S ARTHUR, MB, FFARCS, consultant anaesthetist

Department of Anaesthesia, Ninewells Hospital, Dundee

A L FORREST, MB, FFARCs, consultant anaesthetist

J I M LAWSON, MB, FFARCS, consultant anaesthetist

Department of Anaesthesia, Royal Infirmary, Edinburgh

A H B MASSON, MB, FFARCS, consultant anaesthetist
}

The results suggest that the present regulations on reporting should be revised to focus more attention on the few deaths that occur in patients who have no apparent contraindication to anaesthesia or operation.

\section{Introduction}

The requirement to notify deaths associated with anaesthesia or operation or both to a procurator-fiscal in Scotland or to a coroner in England and Wales was introduced in 1904 (although there have been minor modifications to the regulations from time to time). Deaths in three categories must be reported: (1) death occurring during anaesthesia or operation; (2) death clinically attributable to the anaesthetic; and (3) death occurring in a period not exceeding 12 hours after operation. Inquiries resulting from notification are intended to serve the public interest by establishing whether criminal negligence may have occurred. In almost all cases in Scotland the fiscal's medical adviser conducts a postmortem examination; the report is retained by the fiscal and transmitted to the office of the Lord Advocate. The deceased's doctors are not informed of the findings.

Some anaesthetists believe that the regulations are inappropriate to modern practice, ${ }^{12}$ since techniques of inducing anaesthesia and the distribution of causes of death during and after operation have changed since 1904. That this belief is shared by others is evident from comments in the Report of the 
Committee on Death Certification and Coroners. ${ }^{3}$ In particular, there is irritation and concern at the frequency of formal investigations of this type, including postmortem examination, when a desperately ill patient dies within a few hours of operation and in circumstances that are not surprising to the doctors in attendance.

We have examined the information furnished to procuratorsfiscal from four Scottish teaching hospitals over 10 years and give our opinion on the frequency of reports that prima facie would justify further investigation by the authorities.

\section{Method}

Reports from the Royal and Western Infirmaries, Glasgow; the Royal Infirmary, Edinburgh; and the Royal Infirmary (later Ninewells Hospital), Dundee, during 1967-76 were assessed by two of us. One assessor (ALG) scrutinised all reports. They were placed in one of three categories: (I) death supervening in a patient considered to be moribund and in whom anaesthesia was induced at the request of the surgeon in the tenuous hope of saving life; (II) death for which there was no obvious specific cause not connected with anaesthesia-for example, inability to complete surgical repair of an aortic aneurysm; and (III) death occurring during anaesthesia or shortly afterwards in a patient in whom there was no apparent contraindication to anaesthesia or operation. A note was also made of the age of each patient, the time of death in relation to operation, the duration of the operation, and the seniority of the anaesthetist. We did not include 137 reports of death in patients undergoing cardiopulmonary bypass and have excluded occasional reporting of death in patients aged under 13, since not all of the four hospitals accept children.

\section{Results}

A total of 489 reports were reviewed (table I), and we found no obvious change in the pattern or frequency of reporting during the 10 years. In 459 cases $(94 \%)$ the deaths were in categories I and II ; only $30(6 \%)$ could be placed in category III. Deaths in category I accounted for 287 reports $(59 \%)$.

Death occurred two hours or more after operation in 121 cases $(42 \%)$ in category $\mathrm{I}, 33$ cases $(19 \%)$ in category $\mathrm{II}$, and 11 cases $(37 \%$ in category III, $92(76 \%), 29(88 \%)$, and $7(64 \%)$ of the patients respectively being under the care of a consultant or senior registrar anaesthetist. The predominance of men in all categories was attributable mainly to death after multiple injury or operation for aortic aneurysm, most of the second group being in category II.

Table II lists the anaesthetist's opinion on the causes of death in patients in category III.

TABLE I-General data on 489 deaths in the three categories

\begin{tabular}{|c|c|c|c|}
\hline & & Category & \\
\hline & I & II & III \\
\hline No of patients: & & & \\
\hline Male $\ldots \ldots$ & $171\} 287$ & $\left.\begin{array}{r}123 \\
49\end{array}\right\} 172$ & $18\} 30$ \\
\hline $\begin{array}{l}\text { Female } \\
\text { Mean age in years }\end{array}$ & & & \\
\hline SD (range) & $62 \cdot 4+17 \cdot 98(16-94)$ & $59 \cdot 1: 16 \cdot 38(16-85)$ & $56.6 \pm 18.97(18-84)$ \\
\hline Grade of anaesthetist & & & \\
\hline $\begin{array}{l}\text { Consultant } \ldots \\
\text { Senior registrar }\end{array}$ & $\begin{array}{r}183 \\
35\end{array}$ & $\begin{array}{r}112 \\
39\end{array}$ & $\begin{array}{r}13 \\
6\end{array}$ \\
\hline Junior .. $\quad$. & 67 & 21 & 11 \\
\hline $\begin{array}{l}\text { Other } \\
\text { Time of death: }\end{array}$ & ? & & \\
\hline During operation & 115 & 133 & 13 \\
\hline$-2 h$ after $\ldots$ & 51 & 6 & 6 \\
\hline $2-5 \mathrm{~h}$ after & 41 & 10 & 7 \\
\hline $5-12 \mathrm{~h}$ after. & 49 & 15 & 3 \\
\hline$>12 \mathrm{~h}$ after & 31 & 8 & 1 \\
\hline $\begin{array}{l}\text { Mean duration of } \\
\text { operation (hours) }\end{array}$ & & & \\
\hline $\pm S D$ & $1 \cdot 44 \pm 1 \cdot 21$ & $2 \cdot 13 \pm 1 \cdot 88$ & $1 \cdot 17 \pm 0.87$ \\
\hline
\end{tabular}

TABLE II-Anaesthetist's opinion on causes of 30 deaths in category III

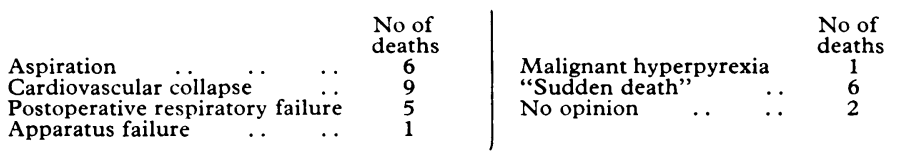

\section{Discussion}

Our analysis suggests that most deaths reported under the present rules occur in patients who are so desperately ill at the time of operation (category I) that the outcome is expected. We think that deaths in category II could be regarded similarly, although owing to the design of the form used for reporting we cannot comment authoritatively on this.

Allocating a report to category III did not necessarily signify that the anaesthetic was the cause of death; even less do we wish to imply that negligence had occurred. Nevertheless, if we had been charged with advising the fiscal we consider that reports in category III would have justified further inquiry either because of the information provided or because of the lack of it. This is not to say that unsatisfactory practice or even negligence could never have occurred in the management of patients in category I (and in category II), but owing to the condition of these patients it would be beyond the present best clinical and scientific capability to establish the fact.

The nature of the inquiries generated by the 489 reports is regarded by the Crown authorities as confidential. Nevertheless, we know that necropsy was performed in most cases, and we understand that most inquiries were concluded after that. We know of no case in which the opinion of an independent anaesthetist or surgeon was sought except for a few cases in category III when a fatal accident inquiry was anticipated or held.

A postmortem examination ordered by the Crown authorities may distress relatives and is an expensive charge on public funds. Most anaesthetists would, in any event, accept that dissection may not be the best way to evaluate the conduct of an anaesthetic. Apart from the belief that such examinations are, on the whole, unrewarding, our results suggest that they are usually unnecessary.

We believe that the present reporting rules could, with advantage, be revised to focus more attention on the relatively few cases such as in our category III rather than on the large remainder. Such a change would serve the public interest better and at less cost.

We thank the Scottish Society of Anaesthetists, under whose aegis this inquiry was conducted.

\section{References}

${ }^{1}$ Lawrie, R, British fournal of Anaesthesia, 1962, 34, 124.

2 Scott, D B, British fournal of Anaesthesia, 1977, 49, 95.

${ }^{3}$ Home Office, Report of the Committee on Death Certification and Coroners, Cmnd 4810, paras 6.31 and 6.32. London, HMSO, 1971.

(Accepted 20 March 1979)

ONE HUNDRED YEARS AGO We read in a daily newspaper that, last week, a public meeting of spiritualists was held at Langham Hall, Great Portland Street-Mr J Enmore Jones presiding. During the evening, several part-songs were sung, and the company joined in hymns provided for the occasion. After various speeches, a rap was distinctly heard behind the Chairman, who said, "Thank you, spirit friend", in acknowledgement of the honour done to the meeting. The Chairman proceeded to relate a spiritual manifestation within his own knowledge. The instance given was of a family gathering at which $\mathrm{Mr}$ Home was present. A music-stool was seen to move from its position near the harmonium, and, ascending to the table, bow three times to the family Bible, which was on the table. The thought occurred to the Chairman that the spirit wanted to convey the idea that music was to be the handmaid of devotion, and, on making the suggestion, the stool at once bowed three times affirmatively, and was helped to the ground by Mr Home. Mr Blake, Mr Humphreys, and others having given their experiences, a discussion ensued on the action of the Lunacy Laws on private and public mediums and others, it being generally thought that the present laws needed amendment. A vote of thanks to the chairman closed the proceedings. (British Medical fournal, 1879.) 